\title{
Hormone replacement therapy prevents bone loss in patients with inflammatory bowel disease
}

\author{
D Clements, J E Compston, W D Evans, J Rhodes
}

\begin{abstract}
Patients with inflammatory bowel disease have an increased prevalence of osteoporosis, and suffer high rates of spinal bone loss. Hormone replacement therapy (HRT) is effective in the treatment and prevention of osteoporosis but has not been studied in patients with inflammatory bowel disease. A two year prospective study of HRT in inflammatory bowel disease was performed in 47 postmenopausal women aged 44 to 67 years with ulcerative colitis (25) or Crohn's disease (22). Patients had radial and spinal bone density measured annually by single photon absorptiometry and quantitative computed tomography respectively. The mean ( $95 \%$ confidence intervals) annual change in radial bone density was $+1.42 \% / y r(+0.58$ to $+2 \cdot 26 ; \mathrm{p}<0.005)$ and for spinal bone $+2.60 \%$ yr $(+1.06$ to $+4.15 ; \mathrm{p}<0.005)$. There was no significant correlation between rates of change of bone density at the two sites, or between the rates of change and the initial bone density either in the radius or spine. Twelve patients were given prednisolone during the study, and their rates of change for spinal bone density were lower, but values were not statistically significantly different from those who did not receive corticosteroids. Changes in bone density for patients with ulcerative colitis and Crohn's disease were not significantly different. The change in bone density did not correlate with the patients' age or number of years after the menopause. It is concluded that HRT is effective in prevention of bone loss in postmenopausal women with inflammatory bowel disease.

(Gut 1993; 34: 1543-1546)
\end{abstract}

Osteoporosis is more common in patients with inflammatory bowel disease (IBD) compared with the normal population, and causes significant morbidity when fractures occur. ${ }^{1-4}$ One study identified that $25 \%$ of women had a bone mineral density more than 2 standard deviations below normals. ${ }^{2}$ Increased rates of spinal bone loss have been reported in some patients and the average spinal bone loss was $3 \% / y r .^{5}$

Hormone replacement therapy (HRT) is effective in the prevention and treatment of postmenopausal bone loss. ${ }^{6-15} \mathrm{HRT}$ also reduces the risk of fracture, but there have been no studies of its effect in patients with inflammatory bowel disease. ${ }^{16-22}$

We have studied postmenopausal women with inflammatory bowel disease given HRT for two years and followed up changes in their bone density by annual measurements. Patients were given a 'standard dose' of oral oestrogen, which has been shown to prevent bone loss in normal women. ${ }^{23} 24$

\section{Methods}

\section{PATIENT DETAILS}

Postmenopausal women with IBD were recruited from a gastrointestinal outpatient clinic. Patients were not included if HRT was contraindicated for medical reasons, such as the presence of an oestrogen dependent tumour or thromboembolic disease. Forty seven postmenopausal women aged 44 to 67 years were studied. The mean age when first measured was 54 years. Ten had had a hysterectomy and their postmenopausal state was confirmed biochemically by measurement of serum gonadotrophins; the age of these patients at their menopause could not be estimated. The average age of menopause in those who had not had a hysterectomy was 48 years (range 42 to 59 ) and they were 5 years (mean; range 1 to 18 ) postmenopausal at the time of the study.

Twenty five had ulcerative colitis (4 total, 3 subtotal, 16 distal, and 2 proctitis) while 22 had Crohn's disease (19 small bowel, 1 ileocolonic and 2 colonic). Fourteen with Crohn's disease had had small bowel resections. The average duration of their disease was 12 years (range 1 to 32). Eight patients were current smokers.

All patients were advised to achieve a daily intake of at least $700 \mathrm{mg}$ of calcium; five patients were unable to take sufficient dairy products to sustain this and were given oral calcium supplements. Vitamin D was not prescribed. None were receiving thyroxine, anti-convulsants, thiazide diuretics, sodium fluoride, calcitonin, or bisphosphonates.

The risks and benefits of HRT were first explained with the aims of the study. All patients were given $0.625 \mathrm{mg}$ daily of oral conjugated oestrogen (Premarin, Wyeth). Thirty seven who had not had a hysterectomy were given cyclic progestogen with 150 micrograms of norgestrel for 12 days each month in addition to $0.625 \mathrm{mg}$ of conjugated oestrogen (Prempak C 0.625 , Wyeth). This dose of oestrogen has previously been shown to be the minimum required to prevent bone loss in normal menopausal women. ${ }^{2324}$

Over the subsequent two years, details of corticosteroid use and surgery were recorded although biochemical parameters were not monitored. There were no adverse effects from the oestrogen therapy apart from breast tenderness in some patients that resolved without treatment. Those receiving cyclic progestogen had regular withdrawal bleeds. 
TABLE I Changes in cortical bone of the radius (BMC/BW; bone mineral content/bone width, $\left.\mathrm{g} / \mathrm{cm}^{2}\right)$ and spinal trabecular bone $(B M D ;$ bone mineral density, $\mathrm{g} / \mathrm{l})$ in forty seven postmenopausal women with inflammatory bowel disease treated with hormone replacement therapy for two years.

\begin{tabular}{|c|c|c|c|c|}
\hline & \multicolumn{2}{|c|}{ First measurement $(n=47)$} & \multicolumn{2}{|c|}{ Third measurement $(n=47)$} \\
\hline & Mean & Range & Mean & Range \\
\hline $\begin{array}{l}\text { Age } \\
\mathrm{BMC} / \mathrm{BW}\left(\mathrm{g} / \mathrm{cm}^{2}\right) \\
\mathrm{BMC} / \mathrm{BW}(\mathrm{Z} \text {-score }) \\
\mathrm{BMD}(\mathrm{g} / \mathrm{l}) \\
\mathrm{BMD}(\mathrm{Z} \text {-score })\end{array}$ & $\begin{array}{l}54 \\
0 \cdot 64 \\
-0 \cdot 19 \\
125 \\
-0 \cdot 79\end{array}$ & $\begin{array}{c}44 \text { to } 67 \\
0 \cdot 39 \text { to } 0 \cdot 84 \\
-2 \cdot 71 \text { to } 3 \cdot 17 \\
72 \text { to } 190 \\
-2 \cdot 71 \text { to } 0.97\end{array}$ & $\begin{array}{c}56 \\
0 \cdot 65 \\
0 \cdot 17 \\
130 \\
-0 \cdot 44\end{array}$ & $\begin{array}{c}46 \text { to } 69 \\
0.37 \text { to } 0.85 \\
-3 \cdot 17 \text { to } 3 \cdot 33 \\
79 \text { to } 201 \\
-2 \cdot 58 \text { to } 1.38\end{array}$ \\
\hline $\begin{array}{l}\text { Change in radial } B M C / B W(n=47) \\
\mathrm{BMC} / \mathrm{BW}\left(\mathrm{g} / \mathrm{cm}^{2}\right) \\
\% \text { Of initial } \mathrm{BMC} / \mathrm{BW} \text { per year of } \\
\text { follow up } \\
\text { Change in } \mathrm{Z} \text {-score }\end{array}$ & $\begin{array}{l}\text { Mean } \\
+0.015 \\
+1 \cdot 42 \\
+0.37\end{array}$ & $\begin{array}{l}95 \% C I \\
+0.004 \text { to }+0.025 \\
+0.58 \text { to }+2.26 \\
+0.16 \text { to }+0.58\end{array}$ & $\begin{array}{l}\text { Range } \\
-0.06 \text { to }+0.09 \\
-3.92 \text { to }+8.69 \\
-1.67 \text { to }+1.66\end{array}$ & $\begin{array}{l}p \\
<0.01 \\
<0.002 \\
<0.001\end{array}$ \\
\hline $\begin{array}{l}\text { Change in spinal BMD }(n=47) \\
\mathrm{BMD}(\mathrm{g} / \mathrm{l}) \\
\% \text { Of initial BMD per year of } \\
\text { follow up } \\
\text { Change in Z-score }\end{array}$ & $\begin{array}{l}\text { Mean } \\
+4 \cdot 8 \\
+2 \cdot 60 \\
+0 \cdot 34\end{array}$ & $\begin{array}{l}95 \% C I \\
\quad 1.07 \text { to }+8.46 \\
+1.06 \text { to }+4.15 \\
+0.22 \text { to }+0.47\end{array}$ & $\begin{array}{l}\text { Range } \\
\quad-28 \text { to }+28 \\
-9 \cdot 5 \text { to }+16 \cdot 2 \\
-0 \cdot 71 \text { to }+1 \cdot 10\end{array}$ & $\begin{array}{l}\stackrel{p}{<0.02} \\
<0.002 \\
<0.0001\end{array}$ \\
\hline
\end{tabular}

BONE DENSITY MEASUREMENT

Bone mineral density was measured at two sites the left radius and the lumbar spine as described previously. ${ }^{25-28}$

Radial bone mineral content was measured at the junction of the distal third and proximal two thirds of the left radius, a site where bone is predominantly cortical, with a single photon absorptiometer based on the design of Cameron and Sorenson. ${ }^{29}$ Results were expressed as the ratio of bone mineral content to bone width $(\mathrm{BMC} / \mathrm{BW})$ in $\mathrm{g} / \mathrm{cm}^{2}$. The long term in vitro and in vivo precision (coefficient of variation) of the technique were estimated from repeated measurements $(n=41)$ over five years. In vitro precision for an aluminium/perspex phantom was $2 \cdot 1 \%$ while the in vivo precision was $2 \cdot 7 \% .{ }^{28}$

Spinal trabecular bone mineral density (BMD) was measured in the anterior part of the first three lumbar vertebrae by quantitative computed tomography (Philips Tomoscan $350 \mathrm{CT}$ scanner) using a modification of the method of Cann and Genant. ${ }^{30} 31$ The bone density was calculated using a calibration phantom containing known concentrations of $\mathrm{K}_{2} \mathrm{HPO}_{4}$ solution

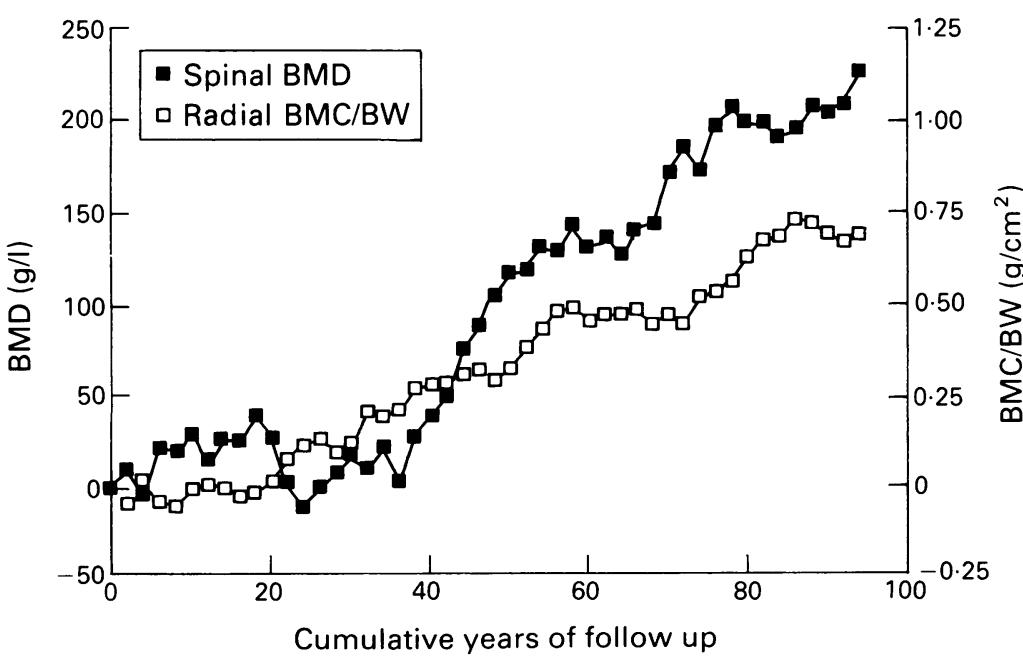

Figure 1: Changes in bone mineral in individual women plotted as the cumulative absolute changes in $B M C / B W$ (bone mineral content/bone width; $\left.\mathrm{g} / \mathrm{cm}^{2}\right)$ in the radius and $B M D($ bone mineral density; $g / l$ ) in the lumbar spine after ranking patients by age - that is, a 'Cusum plot'. The radius is representative of cortical and the spinal vertebrae of trabecular bone. and expressed in grams per litre. The precision of this technique in our hands is $2 \cdot 8 \% .^{225-28}$

Bone density was measured initially and then annually for two years. The same instruments and techniques were used for all the measurements.

\section{DATA ANALYSIS}

Each value of bone mineral content/bone width was converted to a $Z$-score relative to age and sex dependent norms ((patient value - mean)/standard deviation) using the reference data of Ringe. ${ }^{32}$ Each value for bone mineral density was converted to a $\mathrm{Z}$-score (Z-bone mineral density) using the reference data of Cann and Genant. ${ }^{31}$

Each patient had three measurements of bone mineral density and rates of bone loss were estimated by linear regression for each subject. The annual percentage changes in bone mineral content/bone width and bone mineral density were calculated by (slope/intercept) $\times 100$. Statistical analysis was performed using correlation coefficients, $t$ tests, and Mann-Whitney U test. Statistical significance was taken as $\mathbf{p}<0.05$.

\section{Results}

Table I summarises the results.

The mean percentage change for bone mineral content/bone width ( $95 \%$ confidence intervals) was $+1 \cdot 42 \% / \mathrm{yr}(+0.58$ to $+2 \cdot 26)$ and for bone mineral density was $+2.60 \% / y r(+1.06$ to $+4 \cdot 15$ ) (Table I). Figure 1 shows the cumulative absolute changes in radial $\mathrm{BMC} / \mathrm{BW}$ and spinal BMD after ranking each patient by age.

The increase in both forearm and spinal bone mineral density achieved statistical significance in absolute units, percentage per annum, and also in the Z-score. Figures 2 and 3 show the percentage changes in bone mineral density.

There was no significant correlation between the baseline values of $\mathrm{BMC} / \mathrm{BW}$ or $\mathrm{BMD}$ and the subsequent changes in bone mineral or between the rates of change of spinal and radial bone mineral density. There was no significant correlation between the improvements in bone mineral density and the patient's age or the number of years postmenopause.

Twelve patients (seven Crohn's disease) received a mean daily dose of $3.9 \mathrm{mg}$ of prednisolone (range 0.5 to $10 \mathrm{mg}$ ) during the two years. The rate of change of spinal trabecular bone (bone mineral density) was lower in those given corticosteroids, but this was not statistically significant (Table II, Fig 2). The correlations between steroid dose and the changes in bone mineral density were not statistically significant.

Three patients had surgery during the second year of the study; two with total ulcerative colitis had a colectomy, and one patient had a terminal ileal resection. All were given prednisolone before surgery.

There was no significant difference in the response to HRT between patients with ulcerative colitis and Crohn's disease, smokers and non-smokers, and those who had had a hysterectomy and those who had not. There was no significant change in the patient's height, weight, or body mass index during the study. 


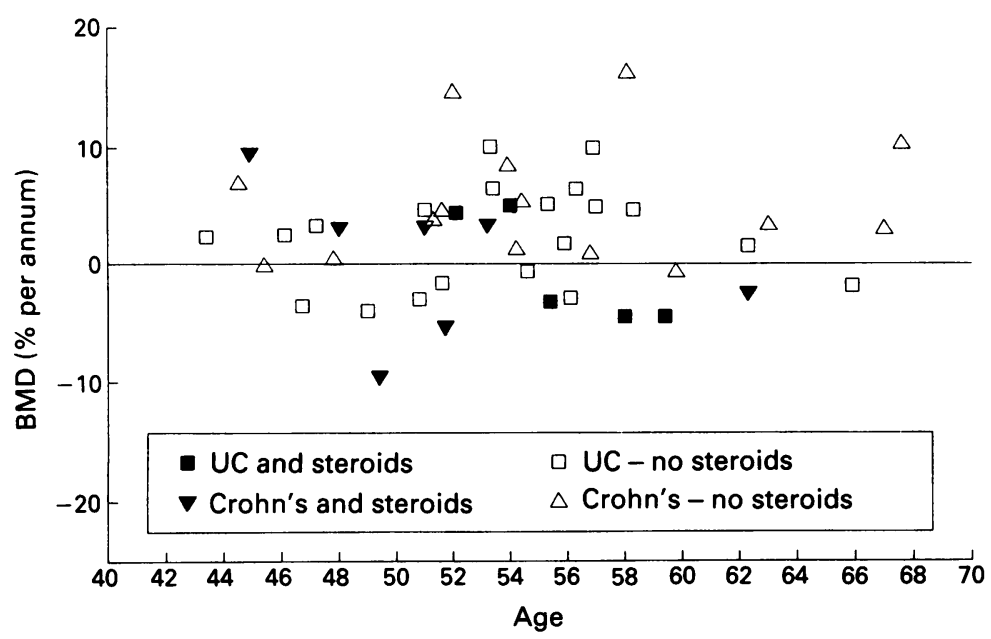

Figure 2: The age of patients at the beginning of the two year study plotted against the subsequent percentage change per annum in spinal trabecular BMD (bone mineral density). $U C=$ ulcerative colitis.

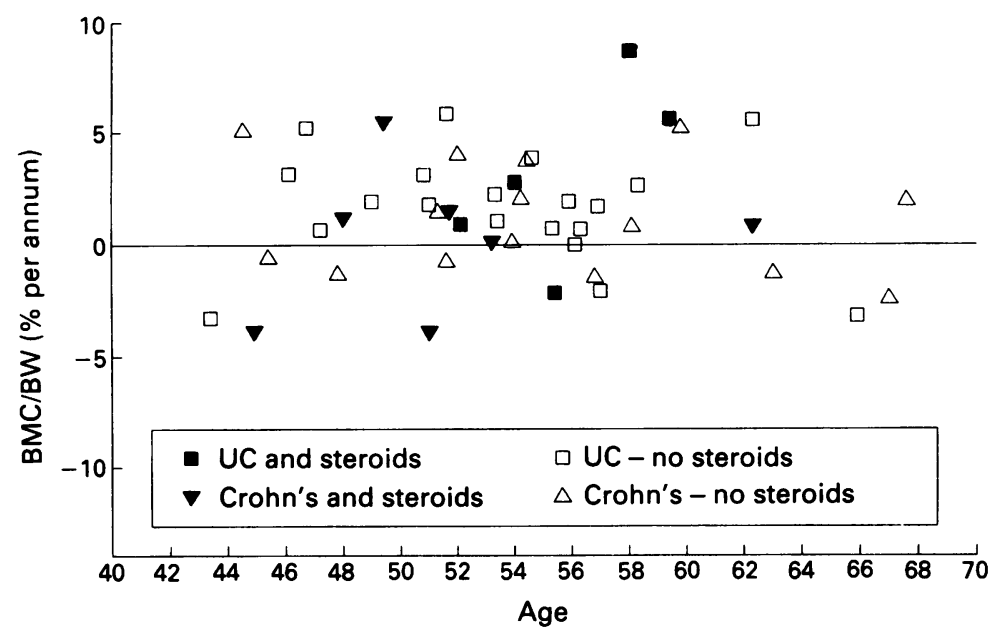

Figure 3: The age of the patients at the beginning of the two year study plotted against the subsequent percentage change per annum in radial cortical BMC/BW (bone mineral content) bone width). UC= ulcerative colitis.

\section{Discussion}

This is the first study of hormone replacement therapy in patients with inflammatory bowel disease. It shows that oral treatment with a standard dose of oestrogen not only prevents bone loss but after two years produced a significant improvement in bone density. The improvement occurred even in women more than 10 years postmenopausal and in both ulcerative colitis and Crohn's disease. The percentage improvement in spinal bone mineral density is similar to that reported in normal

TABLE II Changes in per cent per annum and $Z$-scores of those who did $(n=12)$ and did not receive prednisolone $(n=35)$ during the two year study while treated with hormone replacement therapy (mean; $95 \%$ confidence intervals). BMC/BW= radial bone mineral content/bone width $\left(\mathrm{g} / \mathrm{cm}^{2}\right)$, and $B M D=$ spinal bone mineral density $(\mathrm{g} / \mathrm{l})$

\begin{tabular}{|c|c|c|c|}
\hline & No prednisolone $(n=35)$ & Received prednisolone $(n=12)$ & \\
\hline & $\begin{array}{l}\% \text { per annum } \\
\text { mean }(95 \% C I)\end{array}$ & $\begin{array}{l}\% \text { per annum } \\
\text { mean }(95 \% C I)\end{array}$ & $p$ \\
\hline $\begin{array}{l}\mathrm{BMC} / \mathrm{BW} \\
\mathrm{BMD}\end{array}$ & $\begin{array}{l}+1.42(+0.56 \text { to }+2.29) \\
+3.54(+1.86 \text { to }+5.21)\end{array}$ & $\begin{array}{l}+1.41(-1.01 \text { to }+3.84) \\
-0.11(-3.66 \text { to }+3.43)\end{array}$ & $\begin{array}{l}0.87 \\
0.06\end{array}$ \\
\hline $\begin{array}{l}\mathrm{BMC} / \mathrm{BW} \\
\mathrm{BMD}\end{array}$ & $\begin{array}{l}\text { Change in } Z \text {-score } \\
\text { mean }(95 \% C I) \\
+0.36(+0.13 \text { to }+0.60) \\
+0.40(+0.27 \text { to }+0.52)\end{array}$ & $\begin{array}{l}\text { Change in } Z \text {-score } \\
\text { mean }(95 \% C I) \\
+0.39(-0.12 \text { to }+0.89) \\
+0.18(-0.14 \text { to }+0.51)\end{array}$ & $\begin{array}{l}\mathrm{p} \\
0.98 \\
0.22\end{array}$ \\
\hline
\end{tabular}

women receiving this dose of oestrogen. ${ }^{2324}$ There are no other comparable studies in the prevention of secondary osteoporosis.

Our study did not include a control group. There is already a large amount of data on normal women, which shows that HRT prevents bone loss after the menopause. ${ }^{6-15}$ In addition, without treatment patients with inflammatory bowel disease lose bone at normal or increased rates. ${ }^{24528} \mathrm{We}$ therefore felt it was inappropriate to withhold HRT from some of our patients so that this study was open and prospective, and depend on our previous studies of untreated patients with inflammatory bowel disease for comparison. Our patients treated with HRT, however, show significant improvements in their own right.

A dose response to oestrogens has been shown with increasing doses having greater effects on bone density. ${ }^{12142324}$ In this study, a standard bone sparing dose of oral oestrogen was used. Despite HRT some patients showed a reduction in bone density (Figs 2 and 3). In some this may be a result of an imprecision of the techniques of bone density measurement. Even in normal women on $0.625 \mathrm{mg}$ oestrogen, although overall bone density increases, some still show a reduction. ${ }^{23}$ 24-35 $^{32-3 b s o r p t i o n}$ of the HRT was satisfactory as regular periods returned in those who had not had hysterectomy, menopausal symptoms resolved, and compliance with the treatment was good. Subjects may vary in their response to oestrogens and some may need a higher dose. Future studies should perhaps investigate the effect of increased doses of oestrogen and the value of transdermal administration. ${ }^{36}{ }^{37}$ In some patients the use of prednisolone (or the exacerbation of the inflammatory bowel disease) may have resulted in net bone loss.

Although treatment with prednisolone was associated with reduced improvement in spinal trabecular bone, this was not statistically significant and there was no correlation with the dose. This study is comparatively insensitive, however, for an assessment of the effect of prednisolone because of the one year interval between measurements, the small number of patients given corticosteroids, and the variable dose and duration of treatment. While corticosteroids have an adverse effect on bone mass, this may be partly counterbalanced by improvement in the inflammatory bowel disease. Our findings of an apparently greater adverse effect on trabecular rather than cortical bone is in keeping with other publications on the effect of prednisolone..$^{38} \mathrm{~A}$ recent study has shown that HRT can be effective in preventing bone loss in patients receiving concurrent glucocorticosteroids. ${ }^{39}$

Measurement of bone density is helpful in assessing the risk of oesteoporosis in patients and in monitoring response to treatment. ${ }^{40+1}$ For clinicians without access to bone densitometry, these results are helpful in showing that the improvement with HRT was similar in both Crohn's disease and ulcerative colitis; in addition, the response to oestrogens was not related to the patients age or the number of postmenopausal years.

In view of the increased prevalence of osteoporosis and high rates of bone loss in some 
patients we feel that all postmenopausal women with inflammatory bowel disease should be considered for HRT, particularly in those with extensive disease or those requiring longterm corticosteroid treatment. ${ }^{24} 28$

Corticosteroids have a deleterious effect on bone density that can be reduced by concurrent treatment with HRT. ${ }^{39}{ }^{42}$ Bone mineral measurement allows one of the important complications of corticosteroids to be monitored. The state of a patient's bones and the effect of corticosteroids can be balanced when considering surgery or continued medical treatment. Not all patients on corticosteroids at the same time as HRT lose bone.

We have shown that not only can bone loss be prevented in inflammatory bowel disease with hormone replacement therapy but significant improvements can be achieved.

We are grateful to Dr R G Newcombe for statistical advice. JEC is supported by the Wellcome Trust. Ethical approval for the study was given by the South Glamorgan Joint Ethics Committee.

1 Genant HK, Mall JC, Wagonfield JB, Horst JV, Lanzl LH. Skeletal demineralization and growth retardation in inflammatory bowel disease. Invest Radiol 1976; 11: 541-9.

2 Compston JE, Judd D, Crawley EO, Evans WD, Evans C, Reid EM, et al. Osteoporosis in patients with inflammatory bowel disease. Gut 1987; 28: 410-5.

3 Pigot F, Roux C, Chaussade S, Hardelin D, Pelleter O, Montbrun TDP, et al. Low bone density in patients with inflammatory bowel disease. Dig Dis Sci 1992; 37: 1396-403.

4 Clements D, Motley RJ, Harries A, Rhodes J, Compston JE, Evans WD. Longitudinal study of cortical bone loss in patients with inflammatory bowel disease. Scand $\mathcal{f}$ patients with inflammatory

5 Motley RJ, Crawley EO, Evans C, Rhodes J, Compston JE. Increased rate of spinal trabecular bone loss in patients with Increased rate of spinal trabecular bone loss in patie

6 Lindsay R, Aitken JM, Anderson JB, Hart DM, McDonald EB, Clark AC. Long term prevention of postmenopausal osteoporosis by oestrogen. Lancet 1976; i: 1038-41.

7 Recker RR, Saville PD, Heaney RP. Effects of estrogens and calcium carbonate on bone loss in postmenopausal women. Ann Intern Med 1977; 87: 649-55.

8 Horsman A, Gallagher JC, Simpson M, Nordin BEC. Prospective trial of oestrogen and calcium in postmenopausal women. BMF 1977; 2 : 789-92.

9 Nachtigall LE, Nachtigall RH, Nachtigall RD, Beckman EM. Estrogen replacement therapy I: a 10 -year prospective study Estrogen replacement therapy I: a 10-year prospective study
in relationship to osteoporosis. Obstet Gynecol 1979; 53:27781 .

10 Lindsay R, Hart DM, Forrest C, Baird C. Prevention of spinal osteoporosis in oophorectomised women. Lancet 1980; ii: 1151-3.

11 Jensen GF, Christiansen C, Transbol I. Treatment of post menopausal osteoporosis. A controlled therapeutic trial comparing oestrogen/gestagen, 1,25-dihydroxy-vitamin $D_{3}$ and calcium. Clin Endocrinol 1982; 16: 515-24.

12 Christensen MS, Hagen C, Christiansen C, Transbol IB. Dose-response evaluation of cyclic estrogen/gastagen in postmenopausal women: placebo-controlled trial of its gynecologic and metabolic actions. Am $\mathcal{F}$ Obstet Gynecol 1982; 144: 863-8.

13 Lindsay R. Estrogen treatment of patients with established postmenopausal osteoporosis. Obstet Gynecol 1990; 76: postme 290 .

14 Genant HK, Baylink DJ, Gallagher JC, Harris ST, Steiger P, Herber $M$. Effect of estrone sulfate on postmenopausal bone loss. Obstet Gynecol 1990; 76: 579-84

15 Prince RL, Smith M, Dick IM, Price RI, Webb PG, Henderson NK, et al. Prevention of postmenopausal osteoporosis. N Englf Med 1991; 325: 1189-95.

16 Wallach S, Henneman PH. Prolonged estrogen therapy in postmenopausal women. FAMA 1959; 171: 1637-42.

17 Hutchinson TA, Polansky SM, Feinstein AR. Post-meno- pausal estrogens protect against fractures of hip and distal radius: a case-control study. Lancet 1979; ii: 705-9.

18 Paganinin-Hill A, Ross RK, Gerkins VR, Henderson BE, Arthur M, Mack TM. Menopausal estrogen therapy and hip fractures. Ann Intern Med 1981; 95: 28-31.

19 Kiel DP, Felson DT, Anderson JJ, Wilson PWF, Moskowitz MA. Hip fracture and the use of estrogens in postmenopausal women. N Englf Med 1987; 317: 1169-74.

20 Ettinger B, Genant HK, Cann CE. Long term estrogen therapy prevents bone loss and fracture. Ann Intern Med 1985; 102: 319-24.

21 Weiss NS, Ure CL, Ballard JH. Decreased risk of fractures of hip and lower forearm with postmenopausal use of estrogen. NEngl $\mathcal{F}$ Med 1981; 303: 1195-8.

22 Spector TD, Brennan P, Harris PA, Studd JWW, Silman AJ. Do current regimes of hormone replacement therapy protect Do current regimes of hormone replacement therapy protect against subsequent

23 Genant HK, Cann CE, Ettinger B, Gordon GS. Quantitative computed tomograph of vertebral spongiosa. A sensitive method for detecting early bone loss after oophorectomy. Ann Intern Med 1982; 97: 699-705.

24 Lindsay R, Hart DM, Clark DM. The minimum effective dose of estrogen for prevention of postmenopausal bone loss. Obstet Gynecol 1984; 63: 759-63.

25 Compston JE, Evans WD, Crawley EO, Evans C. Bone mineral content in normal UK subjects. $B r \mathcal{F}$ Radiol 1988; 61: 631-6.

26 Crawley EO, Evans WD, Owen GM. A theorectical analysis of the accuracy of single energy CT bone mineral measurethe accuracy of single energy CT bone
ments. Phys Med Biol 1988; 33: 1113-27.

27 Crawley EO. The determination of elemental composition by quentitative computed tomography. Cardiff: University of Wales College of Medicine, 1989. (Thesis.)

28 Ryde S, Clements D, Evans WD, Motley R, Morgan W, Evans $\mathrm{C}$, et al. Total body calcium in patients with inflammatory bowel disease; a longitudinal study. Clin Sci 1991; 80: 31924.

29 Sorenson JA, Cameron JR. A reliable in vivo measurement of bone mineral content measurements. F Bone foint Surg 1967; 49A: 481-97.

30 Cann CE, Genant HK. Precise measurement of vertebral mineral content using computed tomography. $f$ Comput Assist Tomogr 1980; 4: 493-500.

31 Cann CE, Genant HK, Kolb FO, Ettinger B. Quantitative computed tomography for prediction of vertebral fracture computed tomography
risk. Bone $1985 ; 6: 1-8$.

32 Ringe JD, Rehpenning W, Kuhlencordt F. Physiologische Anderung des Mineralgehalts von Radius und Ulna in Abhangigkeit von lebensalter under Geschlecht. ROEFO 1977; 126: 376-80.

33 Gotfredsen A, Nilas L, Riis BJ, Thomsen K, Christiansen C. Bone changes occurring spontaneously and caused by oestrogen in early postmenopausal women: a local or generalised phenomenon? $B M \mathcal{F}$ 1986; 292: 1098-100.

34 Duursma SA, De Raadt M, Raymakers JA, Haspels AA. Is $1 \mathrm{mg}$ of estradiol valerate or $0.625 \mathrm{mg}$ of conjugated estrogens sufficient for all women to prevent menopausal bone loss? Gynecol Endocrinol 1992; 6: 205-9.

35 Marslew U, Overgaard K, Riis BJ, Christiansen C. Two new combinations of estrogen and progestogen for prevention of postmenopausal bone loss: Long-term effects on bone, calcium and lipid metabolism, climacteric symptoms, and bleeding. Obstet Gynecol 1992; 79: 202-10.

36 Ribot C, Tremollieres F, Pouilles JM, Louvet JP, Peyron R. Preventive effects of transdermal administration of 17Bestradiol on postmenopausal bone loss: a 2-year prospective study. Gynecol Endocrinol 1989; 3: 259-68.

37 Lufkin EG, Wahner HW, O'Fallon WM, Hodgson SF, Kotowicz MA, Lane AW, et al. Treatment of postmenopausal osteoporosis with transdermal estrogen. Ann Intern Med 1992; 117: 1-9.

38 Lukert BP, Raisz LG. Glucocorticoid-induced osteoporosis: pathogenesis and management. Ann Intern Med 1990; 112: 352-64.

39 Lukert BP, Johnson BE, Robinson RG. Estrogen and progesterone replacement therapy reduces glucorticoid-induced terone replacement therapy reduces glucort
bone loss. $\mathcal{B}$ Bone Min Res 1992; 7: 1063-9.

40 Wasnich RD, Ross PD, Heilbrun LK, Vogel JM. Prediction of postmenopausal fracture risk with bone mineral measureof postmenopausal fracture risk with bone mine

41 Hui SL, Slemenda CS, Johnston CC. Baseline measurement of bone mass predicts fracture in white women. Ann Intern Med 1989; 111: 355-61.

42 Hahn TJ, Boisseau C, Avioli LV. Effect of chronic corticosteroid administration on diaphyseal and metaphyseal bone mass. F Clin Endocrinol Metab 1974; 39: 274-82. 